\title{
Heat Shock Protein 90 Alpha Measurement
}

National Cancer Institute

\section{Source}

National Cancer Institute. Heat Shock Protein 90 Alpha Measurement. NCI Thesaurus.

Code C147369.

The determination of the amount of heat shock protein 90 present in a sample. 